\title{
A Forgotten Franco-Irish Literary Network: Hannah Lynch, Arvède Barine and Salon Culture of Fin-de-Siècle Paris
}

\section{Faith Binckes and Kathryn Laing}

\section{(2) OpenEdition \\ 1 Journals}

\section{Electronic version}

URL: http://journals.openedition.org/etudesirlandaises/2477

DOI: $10.4000 /$ etudesirlandaises. 2477

ISSN: 2259-8863

\section{Publisher}

Presses universitaires de Rennes

\section{Printed version}

Date of publication: 30 December 2011

Number of pages: 157-171

ISSN: 0183-973X

\section{Electronic reference}

Faith Binckes and Kathryn Laing, «A Forgotten Franco-Irish Literary Network: Hannah Lynch, Arvède Barine and Salon Culture of Fin-de-Siècle Paris », Études irlandaises [Online], 36-2 | 2011, Online since 30 September 2013, connection on 20 April 2019. URL : http://journals.openedition.org/ etudesirlandaises/2477 ; DOI : 10.4000/etudesirlandaises.2477

This text was automatically generated on 20 April 2019.

(c) Presses universitaires de Rennes 


\title{
A Forgotten Franco-Irish Literary Network: Hannah Lynch, Arvède Barine and Salon Culture of Fin-de- Siècle Paris
}

\author{
Faith Binckes and Kathryn Laing
}

In 1901 Dublin-born writer Hannah Lynch, by then living and working in Paris, wrote to Louise-Cécile Vincens commending her on her latest work and promising that she would include reference to it in her 'Paris Letter': "J'ai reçu et lu en partie votre intéressant livre sur la Jeunesse de la Grande Mademoiselle, dont je rendrai compte dans ma prochaine lettre pour l'Academy ${ }^{1 . "}$ In 1902, the American journalist Katherine De Forest mentioned Lynch's 'Paris Letter' column in the Academy as only one of the many achievements of a successful writer at the height of her powers, "who is said to be the most gifted woman Ireland ever produced ${ }^{2}$ ". Lynch's controversial Autobiography of a Child (1899) had already received a great deal of critical attention in Ireland, England and the United States. Prior to that, she had published several novels, a range of travel writing and literary essays, and her wellreceived French Life in Town and Country was published in 1902. In the same year, Autobiography of a Child was translated into French and serialized in the Revue de Paris. Just as striking then, in the light of these publishing successes, is the general critical neglect of Lynch's work, and her currently low profile in the revised canons of late-nineteenth century Irish writing ${ }^{3}$. An even more neglected figure is Lynch's correspondent, the Parisborn historian, biographer, literary critic and essayist Louise-Cécile Vincens (1840-1908) who published her work under the pen-name 'Arvède Barine ${ }^{4}$. Well established and highly regarded as a salonnière, journalist, historian and moralist in late-nineteenthcentury Paris, she was sought after for her knowledge of foreign languages and literature, and contributed to a wide range of newspapers and periodicals. She was also particularly interested in writing about the lives of women, her portraits of George Eliot and Jane Carlyle in Portraits de Femmes (1887) and La Jeunesse de la Grande Mademoiselle (1901), being two prominent examples. Lynch's personal and professional relationship with Barine (as we will refer to her) provides the focus for our examination of the Paris salon scene and 
in particular the literary networks that informed and enabled Lynch's literary career. A consideration of these networks, and the conversation that we will trace between Barine and Lynch in private correspondence and in the press, offers in particular a unique insight into Lynch's writing at this time, in the context of fevered debate in 1890s Paris about feminism, the New Woman and nationalism.

2 Lynch was no stranger to the excitement and advantages of literary and political networks, and the salon culture often associated with these. The drawing room of her childhood home "was a salon in which nightly assembled a coterie of men and women who represented the talent and education of the Nationalists of Dublin"5. This was a literary salon too, described by Katharine Tynan in her memoir, Twenty-Five Years, and acknowledged as a source for her own literary aspirations: "In [the Lynch-Cantwell] house I really entered the literary atmosphere. One of them was Hannah Lynch, whose novels appealed to the discriminating ${ }^{6}$." Tynan may well have introduced Lynch to the poet and essayist, Mary Robinson and her sister Mabel, establishing one of the most important salon networks for her both in London and Paris. Mary Robinson was famous for her poetry as well as for her salon in London, which was visited by young and wellestablished writers alike ${ }^{7}$. Like many such groupings at the time, it was especially important for women "who used the salon's hybrid structure to build personal and professional ties ${ }^{8}$. When she married the French orientalist, James Darmesteter, in 1888 and moved to Paris, Robinson's attractions as a poet, critic and salonnière moved with her. She was soon as famous in Paris as she had been in London, receiving such guests as Renan, Taine, Bourget and Barrès 9 . Like the London salon, Robinson's Paris gatherings provided writers with all-important connections, and introductions to some of the most prominent and influential Paris salons of the period. One of the most celebrated was the salon of Geneviève Straus, attended by an array of intellectuals, writers, artists and musicians from Henri Bergson to Marcel Proust and Gabriel Fauré, as well as by Irish writers such as Oscar Wilde and George Moore ${ }^{10}$. Lynch's correspondence reveals a connection to this literary milieu through her references to social engagements with Madame Halévy, most probably the wife of Daniel Halévy, who was Straus's nephew and who would become Robinson's biographer. Such structures, which brought together individuals of very different social and literary standing, were essential for writers like Lynch, who was unmarried, living in a foreign country, and who needed to publish in order to make a living.

3 Robinson's salon was a possible first point of contact for Lynch when she settled in Paris, connecting her with several French writers and academics who would play a prominent role in her career. These included the French medievalist Gaston Paris, who held regular Sunday meetings for "friends, pupils and distinguished foreign scholars" 11 . According to the column Lynch published in the Academy just after Paris's death in March 1903, she had known him since the late 1880s, when she first came to Paris with the intention of settling there ${ }^{12}$. This suggests a contact made by way of an existing network, although they developed a friendship outside the parameters of their particular group. Barine, who belonged to one of the most important intellectual circles of the era ${ }^{13}$, knew both Paris and Robinson and evidently ran her own salon too. On a couple of occasions Lynch alludes to conversations which took place in Barine's company, but Jeanne Mairet's 1906 account provides an image of more formal gatherings, taking place weekly and "filled with writers and artists" ${ }^{14}$. Mairet also points out Barine's assertive femininity at these occasions: "The air is heavy with the perfume of flowers, for which the hostess has a passion. When 
many are present, Mme Vincens listens rather than talks"15. This combination of traditional, feminine attributes of reticence and silence, with a powerful intellectual presence also suggested by her masculine-sounding pen name ${ }^{16}$, reveals something of Barine's own complex position with regard to feminist debates of the period ${ }^{17}$.

That Lynch benefited from these connections, and that her work was profoundly affected by them, is clear from the subject matter of her fiction written during the 1890s and the epigraphs she was in the habit of writing. Denys d'Auvrillac: a story of French Life (1896) was dedicated to "Mary James Darmesteter" and the heroine, independent, boyish and determined Mary Sumers, an English girl living in Paris devoted to her art, is partly selfportrait and partly a portrait of her friend. Gaston Paris, whose Medieval French Literature Lynch translated, was also the recipient of the dedication in her short story, "A Page of Philosophy", a narrative that he apparently inspired ${ }^{18}$. Her contacts also provided Lynch with the opportunity of publishing in French journals - an essay on Rudyard Kipling ("Romanciers Anglais Contemporains") in the Revue Bleue (1896) ${ }^{19}$, and most importantly for her, a French translation of her controversial Autobiography of a Child in La Revue de Paris in 1902. Barine, whose associations with La Revue Bleue went back to the start of her own writing career, and who appeared regularly in the Journal des débats, La Revue des Deux-Mondes (which she also helped to edit), and Le Figaro, was the most likely facilitator of Lynch's appearance in the French press. But it is Lynch's unpublished correspondence ${ }^{20}$ which reveals the extent of Barine's significance as a professional contact. For example, it was she who wrote the supportive and enthusiastic review of the French translation of Autobiography of a Child for the Journal des débats in $1902^{21}$. Interestingly, Barine had offered to review this work for the same journal soon after it was published by Blackwoods in 1899. There is no trace of this earlier review, but in a later letter Lynch requested another favour, this time for a review of her forthcoming French Life in Town and Country. Anticipating a less controversial response to this work after the heated debates provoked by the publication of Autobiography, Lynch hoped: "Vous pourrez me faire une appréciation littéraire qui me sera bien précieuse ${ }^{22}$." In this same letter Lynch asked Barine whether she would be prepared to look over the manuscript of the recently translated Autobiography of a Child. This exchange of offers from Barine, and many requests from Lynch, which also includes appreciation of Barine's recent publications and discussion of newly published works in French and English, is characteristic. Invitations to tea and thanks for dinners are interwoven with a more formal, professional conversation about publishing. From the evidence of the letters, Lynch's demands on Barine to facilitate exposure in the French press were quite considerable. But the letters are at times more intimate, providing rare examples of self revelation about her views on woman, nation, and the state of English and French letters - views which, to some extent, they shared.

5 Marked out by her contemporaries as individualist because of her Protestantism, and as a reluctant feminist, or "a feminist without illusions" to quote Ravenal, Barine's contribution to the proliferating debates about women in France at this time was vigorous and complex ${ }^{23}$. 'Féminisme' was a new term, and, as Karen Offen notes: "As in other countries, this neologism covered a broad spectrum of approaches to resolving the woman question, not only in civil and political law but also in education and economic life $^{24}$ ". In relation to some of the debates, Barine presented herself as a conservative, defending, for example, the necessity of a Christian marriage as "un joug moral ${ }^{25}$ " in the face of growing feminist criticism of the institution. But she was also highly critical of the 
ways girls were educated ${ }^{26}$ and her own writing showed a sustained interest in the lives of women and their problematic position in society. Ravenal highlights the tenor of her interests in her reading of Portraits de Femmes:

It is easy to see that Mme Barine's real sympathy and enthusiasm are reserved for Jane Carlyle baking bread in the solitary night watches, and for St Theresa wielding her broom with passionate energy in the intervals of her conference with Popes and Archbishops and of her mystical trances and ecstasies. For these women did not shirk the pettiest detail of their women's lot; their most original and luminous ideas, their most ethereal visions, dawned upon them amid the dust and turmoil of strenuous daily living ${ }^{27}$.

6 This observation also forms a striking parallel with comments Lynch made in a letter to Barine, linking her own concerns about a wider social justice explicitly with the position of women: "Je n'aime que les faibles, les humbles, les déclassés, les malheureuses, les infortunés de la terre et du destin - et de ce côte-là, c'est plutôt les femmes qui s'y trouvent ${ }^{28}$." In this same letter Lynch declares: "Tous mes amis savent que je suis carrément anti-catholique, antimilitariste, anti-nationaliste - que je suis très républicaine", but she does not overtly define herself as feminist. Careful, perhaps, to avoid an already pejorative label and aware of Barine's ambivalent responses to 1890s feminism, Lynch's omission of 'féministe' highlights the anxieties of many women writers preoccupied with gender issues at this time. Elsewhere in her writing Lynch adopted a position similar to high-profile feminists, such as Marguerite Durand, who capitalised upon established notions of femininity while advancing the cause of women's rights ${ }^{29}$. This was an approach Lynch endorsed in her reviews as well as in her fiction at this time. For example, in her 'Paris Letter' of 8 May 1897, Lynch quoted from Mme Daudet's Notes Sur Londres, reflecting on the differences its author had discerned between the English "bluestocking" and many French literary women of the same period:

I do not see here what we call the bluestocking woman using an art as a deliberate originality, making of it a means of effect or seduction or the satisfaction of vanity. These women [authors] have the air of action, of workers, and nearly all maintain their own interests in newspapers and reviews with remarkable good sense and practical view. I do not see amongst them those protegés of directors - those halfactresses, half-authors - who bring feminine letters into disrepute with us. All remain women, and very feminine, and, after an hour of being with them [writing of their club]... I return to my hotel edified by the Englishwoman ${ }^{30}$.

7 Here, while emphasising the fact that they remained "very feminine", Lynch used Daudet to advertise the activities of female intellectual "workers" - a category into which she fell herself. Significantly, however, these literary workers are not only authors, but they also maintain a "club", one of the emblems of modern womanhood which was often associated with the New Woman more specifically.

The fact that women could be distinctly modern, without necessarily conforming to the pattern set by the Anglo-American New Woman, illuminates a point at which Lynch's and Barine's engagement with contemporary feminist discourses intersect again, especially in relation to "La gauche féministe et le mariage". This lengthy piece, part of the "Questions Actuelles' series, now reads like a canon of New Woman authors writing in English. It includes Olive Schreiner, who Barine identifies as "l'évangile de la gauche féministe dans la Grande-Bretagne e $^{31}$ ", Irish writer George Egerton, Grant Allen and Thomas Hardy. For Barine, the emphasis of this emerging canon of writers was a dangerous advocation of "les droits de la passion" 32 ". Barine attacked this "left wing feminism" for what, in her view, was its profoundly naive perspective on female sexual liberation as a mode of social 
reconstruction: "Pauvres filles! Pauvres innocents, d'avoir cru que les hommes n'attendaient que l'heure de la libération pour devenir d'aussi parfaits amants, aussi constants, que les bergers de l'Astree $e^{33}$ !' Lynch was, if anything, even more vociferous in a letter to Barine, where she poured scorn on Allen's The Woman Who Did and Arabella Keneally's Dr. Janet of Harley Street:

Dieu de Dieux, quels livres terribles! Je viens de lire « The Woman Who Did» comment est-ce qu'un public en-dehors d'une maison de santé tolère de pareil imbécilités? Et cet autre, «Dr Janet of Harley Street ». Mais pour quel espèce de gens sont-ils écrits? Le marquis français! Je vous assure, Madame, que la littérature des bonnes et des cuisinières est infiniment supérieure. C'est pire que la dégéneration. On doit crier un " ceaser public » pour empêcher toute personne sans un certificat de médecin pour garantir qu'on n'est pas fou, et un certificat de grammarian pour garantir qu'on sait sa langue, d'écrire ses livres, surtout des romans car on ne lit pas les autres sans une raison $^{34}$.

These rather exaggerated expressions of horror were probably inflected by a touch of pragmatism, considering how important Barine was to her career. But Lynch's protests against these books returned to pragmatic, social concerns apparent elsewhere in her correspondence, once again citing female "workers", albeit of a different kind to that discussed by Mme Daudet. Lynch implies that the "littérature des bonnes et des cuisinières" would be preferable to that of Grant and Kenneally as it would not demonstrate such absolute disassociation from reality. This is emphasised by her reference to "le marquis français" who constitutes a potential audience for Kenneally's book. This is actually a reference to a character in the book itself, the lecherous villain who marries the innocent young heroine in the first chapter, and from whom she escapes before her wedding night. This further emphasises Lynch's observation on the book's disconnection from the world beyond its pages, making a point about a caricature that could be considered to be a feature of contemporary French writing too.

Lynch's most sustained engagement with this caricature, and with the other issues discussed above, was Denys d'Auvrillac, published in the same year as Barine's essay. In her dedication to Mary Robinson she wrote: "In Denys d'Auvrillac you will recognise many a familiar figure of clean-living, honest young Frenchmen who unhappily plays no part in his land's fiction, and is anything but rare in the land's history, actual or past (Paris, May 1896)." The image of a corrupt and decadent marquis is also reversed in the tragic and noble figure of M. Jacques or the Marquis de Civrey, whose fidelity to a beloved but treacherous wife results in his sacrificing the possibility of new love and, in the end, of life itself. It is a complex tale, verging on melodrama at times and drawing freely on the tropes of the New Woman novel too. Mary Sumers is a woman who "lives alone - here, in Paris, anywhere! Who, [...] smokes cigarettes! Who goes on sketching tours, paints, and must necessarily come in contact with all sorts of queer people - disreputable painters ${ }^{35}$ ...", for example, and who "was not a woman who held pronounced faith in marriage in the ordinary way ${ }^{36 "}$. But if the dedication in this novel is presented as part of an on-going conversation with Robinson, the novel itself reads as a lively debate and engagement with many of the themes of Barine's critique of "la gauche féministe". Lynch stages Barine's concerns about the promotion of "les droits de la passion" 37 " at the cost of "le grand contrat 
entre les sexes", where the option of divorce has become "la divinité tutélaire qui préside à la cérémonie nuptuel 38 ". M. Jacques/the Marquis de Civrey refuses to divorce his erring wife and resists Mary Sumer's passionate willingness to compromise her reputation for the sake of love. Denys faces the prospect of a more rational approach to marriage, an arrangement ${ }^{39}$. However, such a practice is called into doubt when he falls first for Mary, and then for the alluring but dubious Madame de la Roche, a kept woman who turns out to be the missing wife of the marquis. Denys is forced to examine his attraction towards both the young and innocent Miss Sumers and 'a fallen woman': "Mary Sumers and Madame de la Roche! Is it so certain that the pure woman is the better of the two ${ }^{40}$ ?" This question is not answered, and the series of crises triggered by passion and the need to impose rationality remain unresolved, leaving the main protagonists unrequited in their desires and alone.

11 Denys d'Auvrillac, therefore, deploys some of the key elements of the New Woman genre to explore some of the possibilities and limits of that genre. It reflects the dialogue between Lynch and Barine, while leaving Lynch room to explore the sort of ambivalence and ambiguity Barine generally avoided. The novel is interested in morality, but it is even more engaged with vexed questions of ethics, and in particular with the conflicting demands of desire and conscience. In her 'Paris Letter' of 12 November 1898, Lynch complained that much modern fiction ignored such questions, once so central to the project of literary realism, and still important to social change: "Why, one asks oneself in wonderment, is modern fiction so monotonously depraved, so drearily cynical, so stupidly false to life?" ${ }^{41}$. But Lynch was not only putting across her view on the sexualisation of literature, and particularly of female characters, here. She was also making a comment on the kind of literary caricaturing that accompanied increasing political factionalism in the wake of the Dreyfus affair. As we will see, Lynch's Parisian networks played an important role in her response not only to anxieties about the moral tone of modern French literature, but about this political crisis too.

As a reviewer of contemporary French books from 1896, Lynch had plenty of opportunities to state her opinion on the condition of fin-de-siècle literature. But the example which most clearly illustrates the intersection between Lynch's views, and those of her influential friends, came in August 1901. Entitled 'Insanity in Literature', it was essentially another 'Paris Letter', depicting a "curious double currency of insanity: the insanity of hate and the insanity of indecency ${ }^{42 "}$ ". Into the first category fell a swathe of anti-Semitic, nationalist novels-most particularly Léon Daudet's Le Pays de Parlementeurs, although 'Gyp' ${ }^{\text {'43 }}$ and Barrès were both roundly condemned for their participation in the "morass of hate invented by nationalism and the Ligue de la Patrie Française ${ }^{44 "}$. However, Lynch was equally hard on the latter tendency, represented by Pierre Louÿs, and his most recent novel Les Aventures du Roi Pausole. She joked that:

Not long ago I heard, at a dinner table, advanced the conclusion that the recovery of the consumptive Pierre Louÿs [...] just after the appearance of his first literary crime, Aphrodite, is a proof against the existence of Providence, for had he died, as all expected then, he would not have perpetrated the worse horrors that have followed $\mathrm{it}^{45}$.

13 This anecdote, heard "at a dinner table", suggests an origin for this dislike of Louÿs' highspirited erotica that extended beyond Lynch's own personal feelings, conjuring the informal critical networks to which we know that she belonged. This became even clearer the following week, when a letter was sent to the Academy protesting against the article. The author took issue with her "violence", her "vehemence - may I say an 'insanity"? - of 
disgust" against anti-Dreyfusards and "the whole school of writers who give to the play of sexual emotion a prominent place in their works", and the "bad taste" of her anecdote about Louÿs. "[...] One cannot help feeling surprised that a residence in France, and (presumably) a superficial acquaintance with the French character, should have been insufficient to save H. L. from so tactless and brutale an exhibition [...] ${ }^{46}$." Lynch's riposte was published on the same page:

It will, perhaps, surprise Mr. Babington to learn that the views I express regarding the works of Pierre Louÿs are those held by every French writer of distinction I have met; and the article I sent you was discussed by me before writing it with two of the greatest French critics of the day, and met with their full approval... The story of M. Louÿs and Providence was told with general approbation at the table of a distinguished writer, where all the guests except myself were writers of scientific and literary renown, and no one found it offensive or "tactless and brutale" as Mr. Babington, with his superior British judgement, states it to be.

[...]

But, alas! second-rate English people and Americans go over to Paris, do Montmartre and the Quarter, and then believe they know all about literary Paris. They think it chic and Parisian to admire fervently all that is basest in modern French letters. It is a way of advertising one's artistic temperament, while all the time, real literary Paris, of which I know something, is much more formal, more correct, more fastidious, than any other literary society of Europe ${ }^{47}$.

This reply attempted to distance Louÿs' work from the "real literary Paris" with which Lynch claimed familiarity - she emphasised this distance by repeating the assertion that Louÿs wrote mainly for the foreign market. There is also an interesting undertone in Lynch's sarcastic dismissal of "superior British judgement", and her pointed observation about the "second-rate English people and Americans" flocking to Montmartre. Although Lynch played down her Irishness when writing for the Academy, her difference is subtly noted here. And, as the controversy rumbled on, it became increasingly apparent that Lynch had touched a nerve not only when it came to perceptions of French literature across the Channel, but concerning notions of decorum in criticism. On the 14 September, Arnold Bennett, a life-long advocate of French literature, wrote in to the Academy in support of Lynch. While he countered her assertion that Louÿs was only really popular abroad, he declared himself in "entire sympathy with the views set forth" in the article, presenting a damning view of current French writing (with the exception of Zola, Bourget, and Anatole France) and praising her energetic critique:

For my part, I enjoyed her vigour. It was needed, and especially in England, where there has been a disposition, even in the most respectable and discreet literary quarters, to take Pierre Louÿs seriously ${ }^{48}$.

15 In the following week, a contributor who signed themselves simply 'Outsider', wrote in to second Bennett's opinion on the French literary export market, and to concur with Lynch in her assessment of Louÿs. However, he noted, "the prominence of pornography in French literature of the day is neither significant, nor, in reality, disquieting", but was part of a French literary tradition to which Villon and Rabelais also belonged ${ }^{49}$.

Although there is no doubting Lynch's position on "pornographic" authors such as Louÿs, these exchanges demonstrate a range of attitudes towards so-called "decadent" writing in the early twentieth-century, and its association with French literary culture in particular. They also reinforce the notion of Lynch as a woman, to borrow Bennett's phrase, "perfectly able to take care of herself" in a clash of opinions. But her commitment to this position was, equally clearly, a product of her personal and professional relationships. 
The "real" literary society she conjured in her response to Babington sounds very much like the salon of Barine, of Robinson, or of Gaston Paris, all individuals of literary or scientific reputation far greater than her own. And, indeed, her private correspondence relating to 'Insanity in Literature' demonstrates just how direct their influence was in this case. One letter in particular, sent to Gaston Paris by Lynch in the immediate aftermath of Babington exchange, shows her anxiety in the face of hostile criticism, the role of Barine in the conception of the piece, and her urgent desire for the help of these friends. She described the "article très fort" which had appeared in the Academy "contre la littérature pornographique" which the English and the Americans thought representative of French literary taste. She noted: "Il y a longtemps que mon amie Arvède Barine me prier [?] de dire [illegible] dans l'Academy." Évidently rattled by Babington's "lettre abusive" with its suggestion that she didn't know her subject, Lynch appealed to Paris to back her up: “ Voudriez-vous écrire tout de suite une courte lettre au rédacteur de l'Academy lui disant que ce que je dis est très vrai pour [?] les français lettrés et réputables ${ }^{50}$." Lynch makes no secret of the fact that it was specifically at Barine's request that the attack upon Louÿs was made. In her column of March 1903, Lynch recalled the affair once again, and on this occasion made Paris's own involvement in it explicit. After he read 'Insanity in Literature', "he wrote and thanked me warmly, saying that no foreigners could find books like those of Louÿs, \&c., more odious than Frenchmen like himself" ${ }^{11}$. If we assume that this account is correct, then Lynch wrote to Paris not simply because of their friendship, but because she knew that he agreed with her.

17 The reciprocal arrangements between Lynch and Barine, and Lynch's appeals to and invocation of, Gaston Paris, present compelling evidence of the power of the salon. And this power was just as apparent when Lynch dealt with the question of the "morass of hate invented by nationalism". In the same March 1903 column, she observed that Paris had not only disapproved of Louys, but had also found the writings of "Gyp' "infamous 52". $^{2}$ Once again, this could have been a moral objection. A hugely prolific popular author, Gyp has been described as a proto New Woman writer. Indeed, Alison Finch describes her character Paulette, as "at first sight the quintessential 'new woman' slangy, cheeky, irreverent, and explicit in her demands for greater sexual pleasure and sexual freedom ${ }^{53}$ ". Although Lynch treated her books as unapologetic froth, the censorious line she took with Allen and Kenneally was conspicuous by its absence. She applauded Gyp's adherence to an "old tradition" in French literature, which aimed not only to "shock", but also to "charm ${ }^{54 "}$ ". But by the later 1890 s, this compliment was made as a point of contrast, framed as part of a criticism of Gyp's current style, which had lost touch with this heritage and had embarked on a different, and darker, course altogether. Gyp was renowned as a nationalist and as a fanatical anti-Semite, who had joined the salon of the Comtesse de Loynes, along with anti-Dreyfusards such as Bourget, Barrès, and Léon Daudet, the other object of Lynch's ire in 'Insanity in Literature ${ }^{55}$. This was, as Braun and Bilski argue, a grouping directly opposed to the Straus salon with which Robinson and Lynch would have been in sympathy ${ }^{56}$. For this reason, Paris might well have found Gyp "infamous" for political, as well as for moral, reasons. In almost the same sentence in which she praised Gyp's former style, Lynch expressed her disgust with the "dismal reading" the novels now provided, with their attacks on republicans, "parvenus", and the Jewish community ${ }^{57}$.

18 This double criticism is important to note, especially when considering the influence of Barine. When briefly referring to her article on new women and "la gauche féministe", 
Offen assumes that Barine was on the same side as Maurras and L'Action française. In other words, because she was conservative in her feminism, her most natural alliance would be with thinkers from the far right ${ }^{58}$. But, as Ernot's article and Barine's correspondence demonstrates, her position was more complex. Ernot argues that she was influenced by Ferdinand Brunetière - and Barine certainly did evince a conservative respect for French institutions ${ }^{59}$. But, while Lynch avoided describing herself as a feminist in her correspondence with Barine, she was happy to announce her opposition to the Ligue and her position as "carrément anti-nationaliste", suggesting that Barine took a rather different line. A final, and direct, illustration of this can also be found in Lynch's correspondence, this time relating to an article she had published in the London Contemporary Review in 1902. In this piece, Lynch ruthlessly mocked Bourget's novel L'Etape, which, she argued, not only wallowed in ill-conceived nationalist nostalgia for the Ancien régime, but demonstrated the hypocrisy of Bourget's recent professions of piety. Lynch enquired, had Bourget changed so much from "those far-off times of remunerative depravity":

Those wicked days, however, are over, and the mystic has nearly killed the sensualist. Not quite, for it is clear that the fiction of M.Bourget even in its new phase can never shake itself free of the obsession of the bachelor's flat for the inevitable seduction or adultery. Régimes may pass and Republics may go, but woman ever remains for the eminent M.Bourget a creature of vaporous underwear and man the eternal explorer of her charms ${ }^{60}$.

Lynch's article killed several birds with one stone, combining social, religious, and gender politics in order to comprehensively dismiss Bourget's position. Rather than associating an over-riding interest in female sexuality purely with decadent or naturalist authors, Lynch made the same case against a writer who was claiming to have cornered the conservative moral high ground. This completed a similar manoeuvre to 'Insanity in Literature', which had overtly connected indecency and prejudice with its parallel critiques of Louys and of Léon Daudet. And, once again, Lynch was writing for the approval of her friends in Paris, as much as she was for her readers in London. On 16 September 1902, she wrote to Barine about the response to her Contemporary Review article, regretting that Barine had not been there to share it: "On le trouve d'une férocité excessivement drôle - M. Gaston Paris m'a écrit que c'est 'brillant et fulgurant' ${ }^{61}$."

From the mid-1890s onwards then, Lynch's correspondence, her literary criticism, and novels such as Denys D'Auvrillac give a direct insight into the ways in which the literary networks to which she belonged in Paris impacted upon her profile, and upon the positions she assumed. Lynch's Parisian friends were far more than companions--they involved her in reciprocal exchanges with thorough-going consequences for her writing on modern women, on nationalism, and even on religion. By the end of her life, committed to France - "votre pays qui me plait plus que tout autre" as she wrote to Barine and with no plan to return to Ireland, Lynch clearly saw herself becoming a permanent émigré, like her friend Mary Robinson ${ }^{62}$. Poignantly, her early death left unfinished a novel which those who read it considered to have been her finest work to date-a book set in Paris, which remains lost. Uncovering Lynch's archive, therefore, goes some way to recovering such losses, and restoring the contribution of an author whose engagement with the burning issues of her day demonstrates a commitment to social justice that grew from, but was in no way restricted to, the context of her home nation. It also adds a valuable new perspective on the nuances of feminism as a transnational phenomenon, in which conservative commentators, such as Barine, played significant and active roles. And finally, the study of literary networks such as those with which Lynch, Robinson, and 
Barine were involved offers a way into the intricate relationships underpinning more monolithic historical and literary narratives of the Irish diaspora.

\section{NOTES}

1. Lynch to Barine, mss letter, n.d. 1901, BNF, NAF, 18345, f. 332. Lynch's correspondence with Barine and Gaston Paris is held in Nouvelles Acquisitions Françaises, Bibliothèque Nationale de Paris.

2. Katherine De Forest, "Recent Happenings in Paris", Harpers Bazaar, 1902, p. 813.

3. Discussions of Lynch in recent scholarship indicates a critical shift in the status of her work. See, for example James Murphy, Irish Novelists and the Victorian Age, Oxford, OUP, forthcoming 2011, and J. W. Foster, Irish Novels: New Bearings in Culture and Fiction 1890-1940, Oxford, OUP, 2008.

4. Isabelle Ernot, who provides the fullest portrait to date of Barine's writing and position as a major intellectual of her time, also notes this neglect. See her "Une historienne au tournant du siècle: Arvède Barine" in Persée No. 16, 1998, p. 93-131. [http://www.persee] (accessed 15/9/10) and "L'histoire des femmes et ses premières historiennes (xIX ${ }^{\mathrm{e}}$-début $\mathrm{xx}^{\mathrm{e}}$ siècle" in Revue d'Histoire des Sciences Humaines 2007/1 (No. 16). Two essays by Barine's contemporaries provide further insight: Florence Ravenel's "A Woman Critic of Woman" ( North American Review, 1911) and Ernest Tissot's Princesses des Lettres (Paris, Fontemoing \& Cie, 1911), which also includes an essay on Mary Robinson.

5. From John P. Gibbs's obituary: "Tribute to Hannah Lynch: An Irish woman of Great Literary Ability who did Hard Work in the Parnell Movement", Gaelic American, 13 Feb 1904. Her step-father, James Cantwell, was a Young Irelander and one of the men of 48 and her mother, Anna Theresa Calderwood, had nationalist and literary leanings.

6. Katharine Tynan, Twenty Five Years: Reminiscences, London, Smith Elder, 1913, p. 76.

7. See Ana Parejo Vadillo, "Immaterial Poetics: Mary F. Robinson and the Fin-de-Siècle Poem" in The Fin-de-Siecle Poem: English Literary Culture and the 1890s, Ed. Joe Bristow, Athens, Ohio University Press, 2005, p. 240.

8. Ana Parejo Vadillo, "Aestheticism 'at home' in London: A. Mary F. Robinson and the Aesthetic Set" in London Eyes: Reflection in Text and Image, eds. Gail Cunningham and Stephan Barber, United States, Berghan Books, 2007, p. 75.

9. Alain Silvera, Daniel Halévy and His Times: A Gentleman-commoner in the Third Republic, Ithaca, Cornell UP, 1966, p. 35.

10. Emily D. Bilski and Emily Braun, Jewish Women and Their Salons: The Power of Conversation, New Haven and London, Yale UP, 2005, p. 72.

11. Catholic Encyclopaedia, [www.newadvent.org/cathen/11498b.htm].

12. 'H. L.', "Paris Letter”, Academy, 14 March 1903, p. 224-225.

13. Ernot, "Une historienne au tournant du siècle", p. 96. 
14. There are several connections to be made between Barine and Robinson, one of them being that they both sat on the first committee for the all-female Prix Femina literary award. See Margot Irvine, "Une Académie des Femmes?" in M. Irvine (ed.) Les réseaux des femmes de lettres au XIX sièle (@nalyses, 2008), 24. [http://www.revue-analyses.org/index.php? $i d=1127]$.

15. Jeanne Mairet, "Reminiscences of a Franco-American", The Critic, 49/3, September 1906, p. 217.

16. This name might have sounded masculine but it hinted at a more complex identity. According to Barine herself, the name "avait l'avantage de n'être ni homme, ni femme, ou plutô $t$ il était les deux". Cited in Ernest Tissot's biography in his Princesses des Lettres (Paris, Fontemoing \& Cie, 1911), p. 62.

17. See Ernot on the paradoxes of Barine's character and writing, including the conflict between her prominence as an intellectual and public figure and "sa volonté d'être discrète, voire effacée", p. 94.

18. Lynch acknowledges this debt in a letter to Gaston Paris in 1895 (BNF:NAF 24447, f.228). For more discussion of this story, see our "From 'Wild Irish Girl' to 'Parisianised Foreigner", p. 46-47.

19. Revue Politique et Littéraire: Revue Bleue, Numero 18, 31 octobre 1896, p. 554-557. A short review of Denys d'Auvrillac appeared in the Revue Bleue in 1897 (Vol. 8, No.15, p. 479).

20. The letters from Barine to Lynch have been lost or are yet to be discovered.

21. Dimanche 6 juillet 1902, p. 3. Review of Très Véridique Histoire d'un Petite Fille by Arvède Barine.

22. Lynch to Barine, mss letter, Jan 29 1900, BNF, NAF, 18345, f. 322.

23. Ravenal, p. 902. See also Ernot's fuller discussion of Barine's paradoxical feminism: "si Arvède Barine n'a participé à aucun mouvement féministe, elle a une pensée profonde et originale sur la question féminine" op. cit., p. 94.

24. Karen Offen, "Depopulation, Nationalism and Feminism in fin-de-siècle France" in The American Historical Review, Vol. 89, No. 3 (June 1984), p. 654.

25. Arvède Barine, 'La gauche féministe et le mariage', Revue des Deux Mondes, 1 July 1896, p. 126.

26. "Loin d'être favorable au développement de l'âme féminine, l'éducation des jeunes filles, telle qu'elle est aujourd'hui pratiquée, lui cause, au contraire, un tort considérable", cited in Tissot, p. 23.

27. Ravenal, p. 897.

28. Lynch to Barine, mss letter, n.d. [1901], Wednesday, BNF, NAF Vol 18345 f. 330.

29. See Maggie Allison's chapter on Durand in Diana Holmes and Carrie Tarr (eds.) A Belle Epoque? Women in French Society and Culture, 1890-1914. New York \& Oxford, Berghahn, 2006, p. 37-50. Durand, like Barine, wrote for Le Figaro.

30. “H. L.', "Paris Letter", Academy, 8 May 1897, p. 501.

31. Barine, «La gauche féministe et le mariage », p. 109.

32. Ibid., p. 125.

33. Ibid., p. 130. Barine also notes here that the legal aspect of marriage not only protects women, but children too, a subject "dont on s'occupe vraiment trop peu entre romantiques ou féministes", p. 131. 
34. Lynch to Barine, mss letter, [Mardi, n.d.], BNF, NAF 18345 f. 316.

35. Hannah Lynch, Denys d'Auvrillac, p. 124-125.

36. Ibid., p. 15.

37. Barine blamed the Romantics for promoting this doctrine in the first place, and she is especially disapproving of Georges Sand. Lynch, who was an admirer of Sand, seems rather playfully to pick up on this when Denys d'Auvrillac, in the throes of hopeless passion for Mary, is discovered reading Byron in translation (p. 234). Further evidence of playful conversation around Sand is in Lynch's naming the Marquis de Civrey in disguise as M. Jacques, the title of one of Sand's novels which, like Denys d'Auvrillac, involves a love triangle.

38. Barine, "La gauche féministe", p. 125, 130 and 131 respectively.

39. Barine is particularly hostile to the practice of arranged marriages. See Ernot, p. 123.

40. Hannah Lynch, Denys d' Auvrillac, p. 231.

41. 'H. L.', “Paris Letter”, Academy, 12 November 1898, p. 254.

42. 'H. L.', "Insanity in Literature”, Academy, 17 August, 1901, p. 137.

43. 'Gyp' was the pseudonym of Sibylle-Gabrielle Marie-Antoinette de Riquetti de Mirbeau, comtesse de Martel de Janville. Willa Silverman, author of The Notorious Life of Gyp: Right-Wing Anarchist in Fin-de-Siècle France (New York, Oxford University Press, 1995) and of numerous articles, is probably the authority on her life and work.

44. 'H. L.', “Insanity in Literature”, Academy, 17 August, 1901, p. 137.

45. 'H. L.', op. cit., p. 138.

46. Percy L. Babington, "Insanity in Literature”, Academy, 24 August 1901, p. 159.

47. 'H. L.', untitled response to Babington, Academy, 24 August 1901, p. 159.

48. E. A. Bennett, "Insanity in Literature”, Academy, 14 September 1901, p. 227.

49. 'Outsider', “Insanity in Literature”, Academy, 21 September 1901, p. 247.

50. Lynch to Paris, mss letter, 20 August 1901, NAF 24447, ff. 232-233.

51. 'H. L.' "'Paris Letter”, Academy, 14 March 1903, p. 255.

52. 'H. L.', op.cit., p. 255.

53. Alison Finch, Women's Writing in Nineteenth Century France. Cambridge, Cambridge University Press, 2000, p. 181-183.

54. 'H. L.', “Paris Letter”, Academy, 5 March 1898, p. 265.

55. See Ruth Harris, "Salonnières Left and Right" in The Man on Devil's Island: Alfred Dreyfus and the Affair that Divided France. London, Allen Lane, 2010, p. 273-295.

56. Bilski and Braun, op. cit., p. 75.

57. 'H. L.', “Paris Letter”, Academy, 5 March 1898, p. 265.

58. Offen, p. 662.

59. While Brunetière was definitely anti-Dreyfusard, Harris elaborates on the complicating elements of his position in The Man on Devil's Island, pp.146-153. Lynch's discussion of Brunetière's 1899 speech at the Académie Française noted his intellectual and rhetorical appeal, but was unwaveringly critical of his position as the "lay pontiff of the Reactionary Party". "Paris Letter”, Academy, 2 December 1899, p. 635. 
60. Hannah Lynch, "Paul Bourget, Preacher", Contemporary Review Volume 82, July-Dec 1902, p. 353.

61. Lynch to Barine, mss letter, September 16, 1902, BNF, NAF 18345, f. 334.

62. Lynch to Barine, mss letter, 29 January 1900. BNF, NAF 18345, f. 322.

\section{ABSTRACTS}

This paper is an exploration of Irish émigré author Hannah Lynch (1859-1904), her participation in the salon culture of the Parisian belle époque, and the impact of these social and literary networks on her career. We will focus in particular on her relationship with the historian, biographer, and literary critic 'Arvède Barine' (Louise-Cécile Vincens), drawing upon Lynch's unpublished letters to Barine, upon their respective articles on feminism, politics, and French literature, and upon Lynch's 1896 novel Denys D'Auvrillac. We will more briefly discuss Lynch's association with other notable figures such as the poet Mary Robinson, who held her own Paris salon after her marriage to James Darmesteter, and the medievalist Gaston Paris, with whom Lynch also corresponded. By examining Lynch's negotiations within a complex and combative field, we will argue for a reading of her work that engages fully with her French context and influences during this period, and bring to light a provocative Irish voice largely absent from accounts of the late nineteenth-century diaspora.

Cet article évoque le parcours de la romancière émigrée irlandaise Hannah Lynch (1859-1904), sa participation à la culture des salons parisiens de la Belle Epoque, et l'impact de ces réseaux sociaux et littéraires sur sa carrière. Nous nous attarderons en particulier sur sa relation avec l'historienne, biographe et critique littéraire "Arvède Barine» (Louise-Cécile Vincens), en nous appuyant sur ses lettres inédites adressées à Barine, sur leurs articles respectifs sur le féminisme, la politique, et la littérature française, et sur le roman de Lynch paru en 1896, Denys D'Auvrillac. Nous discuterons plus brièvement de l'association de Lynch avec d'autres figures notables telles que la poétesse Mary Robinson, qui tenait son propre salon après son mariage avec James Darmesteter, et le médiévaliste Gaston Paris, avec lequel Lynch correspondait. En analysant la façon dont Lynch se positionna dans un milieu militant complexe, nous montrerons qu'il faut lire l'œuvre de Lynch à la lumière de son environnement français et des influences dues à l' époque, et nous soulignerons la nature provocatrice de cette voix irlandaise largement ignorée par l' histoire de la diaspora de la fin du XIX ${ }^{\mathrm{e}}$ siècle.

\section{INDEX}

Keywords: feminism and post-feminism, diaspora, women and femininity, Lynch Hannah, Irish nationalism, Franco-Irish relations, activism

Mots-clés: diaspora, féminisme et post-féminisme, femmes et féminité, Lynch Hannah, militantisme, nationalisme irlandais, relations franco-irlandaises 


\section{AUTHORS}

\section{FAITH BINCKES}

Worcester College, University of Oxford

\section{KATHRYN LAING}

MIC, University of Limerick 